DOI: $10.31471 / 2311-1399-2019-2(12)-41-47$

\title{
Hydrophobization method and "Ramksis-2" material for the flow rate in crease in the watered oil wells
}

\author{
V. N. Babaev, I. I. Kaptsov, O. I. Nalyvaiko* \\ O.M. Beketov National University of Urban Economics; \\ 17, Marshala Bazhanova street, Kharkiv, 61002, Ukraine
}

Received: 21.09.2019 Accepted: 25.10.2019

\begin{abstract}
In the article there is made an attempt to investigate the most effective methods of petrofeedback increasing and wells productivity in the conditions of Ukrainian oil and gas fields. Traditional methods petrofeedback increasing and new approaches of solving this problem, such as hydrophobization layer zones or the use of water-swellable polymers are also considered. Particular attention is given to the processing of studies of cores of flooded wells to determine the coefficient of permeability recovery after injection of hydrophobic suspension "Ramsinks-2". The material significantly increases the injectivity of the well, reduces the injection pressure by improving permeability of the formation. It is shown that the use of hydrophobic materials "Ramsinks-2" and "Silpan-SV" in wells allows almost completely restore the filtration characteristics of the producing formation by increasing the oil component in the oil-water mixture.
\end{abstract}

Keywords: hydrophobisation, oilfield, oil recovery, reservoir.

\section{Relevance of work}

In modern conditions, the share of hard-to-recover reserves in the overall balance of hydrocarbons is constantly increasing. At the same time, the share of highly-watered and low-rate wells in the general fund increases, the negative role of contamination (skin effect) in the bottom area of the production wells increases, the oil recovery of the reservoir decreases due to the formation of washed zones from the injection wells and the development of heterogeneity, and the formation energy is reduced. In the conditions of deposits with an inhomogeneous permeability of the reservoir (the presence of a plurality of separate sublayers, a monolithic layer with inhomogenity in permeability), these problems only increase [1]. In this connection, the complex use of technical, organizational and economic tools for improving the efficiency of subsoil use acquires particular importance.

The purpose of this article is to analyze new approaches to solve the problem of stabilizing oil and gas extraction of oilfields at the late stage of their development.

\section{Material and results of research}

The increase of the final coefficient of extraction of hydrocarbons from the productive formation at the final stage of development is ensured by the increase in the hydrocarbon flow rate and the achievement of the hydrodynamic perfection of the well, the increase of the

* Corresponding author: nalivayko.60@ukr.net

(C) 2019, Ivano-Frankivsk National Technical University of Oil and Gas.

All rights reserved. hydraulic conductivity and the purification of the bottom hole area of the formation from pollution, reducing the water level of the extracted product, increasing the formation area by flooding and equalizing the profile of the intake capacity of injection wells $[2,3]$.

The increase in hydrocarbon production is achieved by increasing the production capacity of the well. The maximum effect of the stimulation of production will be achieved as a result of simultaneous improvement of the filtration characteristics of the reservoir, expansion of the well supply circuit and the strengthening of the hydrodynamic bond with the remote zone of the formation. The hydrodynamic perfection of the well penetration is provided by the addition or re-perforation of the well with standard or slowly burning charges, which allows to increase the flow rate of the production wells and increase the intake of injection wells. In the conditions of old production wells, re-perforation is carried out in the medium of active technological solutions. At the same time, for the specific conditions of various deposits, optimal compositions of perforation fluids have been developed. For example, for fields with active oil and high water levels (Dolyna oilfield district), water-based micellar solutions are used. For oilfields with hydrophobic reservoirs or high viscosity oil (Chernihiv and Okhtyrka districts), surface-active systems with increased permeability are used as a technological solution.

In order to minimize the negative influence of perforation fluids on the permeability of the formation and the partial impact on the bottom zone, optimal compositions of micellar solutions and surface-active systems with different densities have been developed. The use of active technological liquids during repeated perforations of the productive layers has made it 
possible to significantly increase their efficiency and increase the flow rate of wells. For example, for the Skorohodiv oilfield (the presence of hydrophobic reservoirs), this method is the only highly effective way to influence the formation - chemical methods of exposure or is ineffective, or generally reduce the productivity of the formation [4].

After a long extraction of oil from the well, the filtration properties of the oil reservoirs gradually deteriorate, the composition of the water-oil emulsion changes, and the water cut of the wells increases. As a consequence of these changes, the share of hard-toreach oil reserves in the general balance reaches $60 \%$, the share of heavily water-producing and low-rate wells throughout the stock increases, the negative role of pollution in the bottom-hole area of the production wells increases, and the oil recovery of the formation decreases due to the formation of washed zones [6].

Technology of impact on the reservoir and the application of these or other reagents depends on the geological and industrial conditions of the specific field and the nature of the contaminants introduced. Over the past ten years, over 50 operations have been carried out using alkaline-acid solutions in the Okhtyrka, Dolyna, Poltava and Boryslav oilfields. The efficiency factor was $74 \%$, and the additional production per treatment was 550 tonnes. At the same time, the increase in the flow rate of wells by liquid is from 120 to $370 \%$.

The basis of the new hydrophobic dispersion is silicon dioxide at chemical modification of surface of the initial material of organoelemental compound of the general formula, $\mathrm{Cl}_{4}-{ }_{n} \mathrm{SiR}_{\mathrm{n}}$, where $\mathrm{n}=1-3, \mathrm{R}=\mathrm{H}$, methyl-, ethyl-, Cl-methyl, phenyl-, with further chemical treatment.

Hydrophobic dispersion material is applied with success in watercut producing wells, different in permeability and degree of watercut of oil and gas production formation. Depending on the formation the well consumes from $40-50 \mathrm{~kg}$ up to $120-150 \mathrm{~kg}$. The effect occurs within 2-4 weeks after the treatment and lasts from 6 up to 18 months, after which the wells requires reprocessing. The results of the application of an experimental batch of new hydrophobic material on the well of Zhyrnovsk field No 193, RF, and on the fields of State Joint Stock Company "Ukrnafta", Ukraine (Staroselsk field, Boryslav field, Ukraine), confirmed the high technical and economic efficiency: after the "Ramsinks-2" material was hydrophobized in the production watercut areas, the increase in well flow rate is $200-400 \%$ (Fig. 1, Fig. 2).

All other wells were with low-permeable reservoirs from 10 to $50 \mathrm{mDa}$ and after stimulation with materials from the "Ramsinks-2" group, their additionally obtained flow rate was in the range of 70$250 \%$. To demonstrate the capabilities of the hydrophobic material "Ramsinks-2" to increase the flow rate of watered oil and gas wells, we conducted the most effective example obtained from well No 193. Payback of the production well after processing using standard techniques and standard equipment, the cost of kerosene or light oil fractions, 72-hour of well downtime, cost of hydrophobic dispersion material is from 1 up to 2 months depending on the well production rate.

The unique hydrophobic material "Ramsinks-2" and the technology of its application have been developed and protected by the patent of Ukraine No 4700 (Method of obtaining a hydrophobic substance on the basis of sedimentary siliceous rocks), the patent of Ukraine No 32045 (Solutions for selective processing of oil reservoirs "Silpan-SV") patent of Ukraine No 31700 (Method of selective acid treatment of formations) and patents of the Russian Federation: patent RU No 2188933 (Method for increasing the productivity of wells), patent RU No 2188215 (Method for producing a hydrophobic dispersed material).

The proposed technological solution is the treatment of the reservoir with the hydrophobic reagent "Ramsinks-2", which allows to increase the oil component in the water-oil mixture that is extracted from the oil well. The essence of this process consists in the formation on the surface of pores and capillaries of molecular adsorption films from oriented asymmetricpolar molecules that are converted by hydrocarbon radicals to the outside. These radicals are hydrophobic, i.e. have water-repellent properties. Experimental studies on samples of natural cores showed that the hydrophobic material "Ramsinks-2", developed on the basis of a complex chemical reaction, is a soft-action blocking material that partially reduces the permeability of the reservoir. Reducing the permeability of the watersaturated formation due to its injection is $9-32 \%$ of its initial value. In this case, the recovery factor depends on the initial permeability of the rock sample - with its increase, the permeability recovery coefficient also increases. For oil-saturated samples are characterized by higher recovery rates - from 20 to $98 \%$. Due to the hydrophobization of the pore surface, the share of oil with a constant supply of emulsion increases by 10 $15 \%$. Industrial tests of the hydrophobic reagent "Ramsinks-2" at the wells of OGPD "Boryslavnaftogaz" of PJSC "Ukrnafta" in 2004-2007 confirmed the results of experimental works - the reduction of water cut was $7-15 \%$ [4].

In some cases, by blocking watered zones and restoring the permeability of contaminated sublayers, an increase in well production by $200-350 \%$ was observed. Reagents of the recommended compositions are adsorbed on the surface of the pore channels and, due to this, are not washed out for a long time from the productive formation. Since the composition is injected into the formation as a suspension, it will penetrate into the pore channels of only with reservoir permeability from $10 \mathrm{mDa}$. For the collectors of the Boryslav oilfield area, the injection of a suspension of the "Ramsinks-2" material is possible in layers with a permeability of more than $15 \mathrm{~nm}^{2}$ (Table 1).

During the research it was found that in the samples with a permeability of less than $15 \mathrm{~nm}^{2}$, the "Ramsinks-2" suspension practically does not penetrate. For the accumulation at the entrance edge of the core, its permeability decreases to a value of $21 \%$ of the initial value. 
$\%$

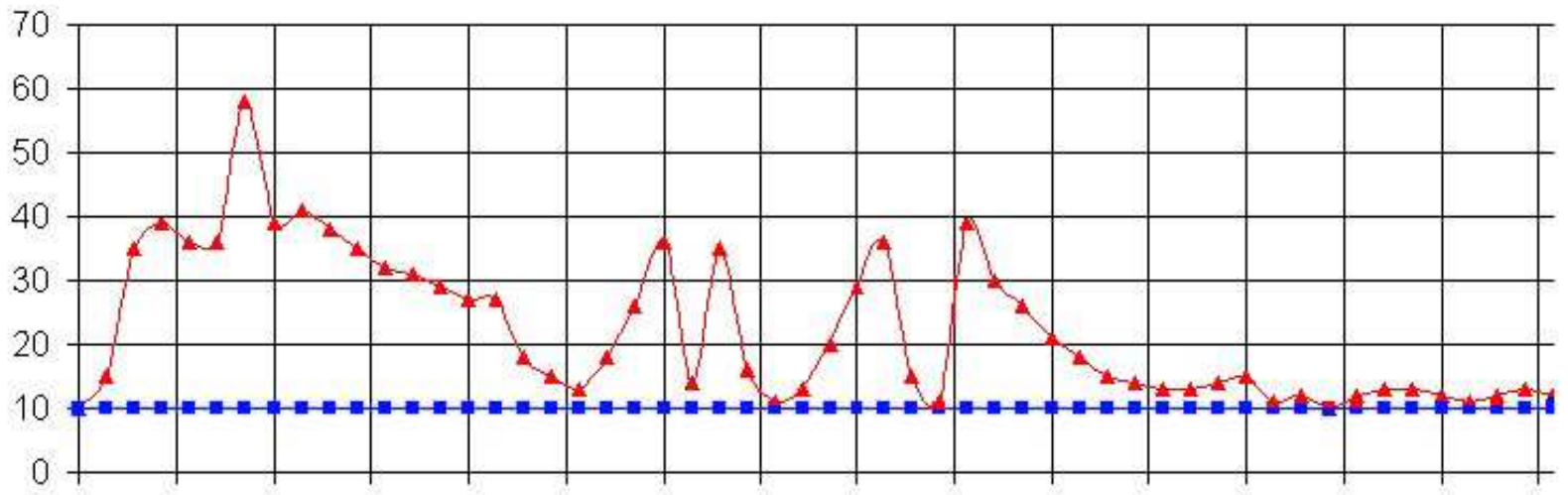

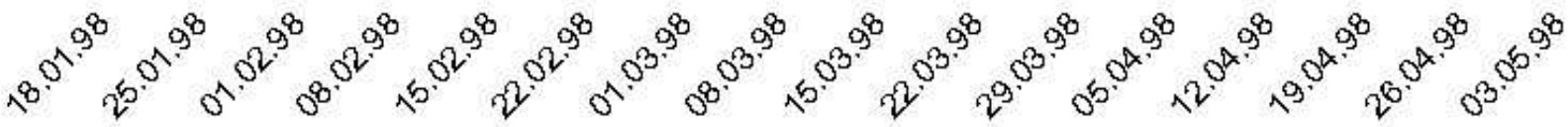
$₫$ Oil content after processing

\section{- Oil content before processing}

Figure 1 - The increase in the oil phase after treatment with hydrophobic material
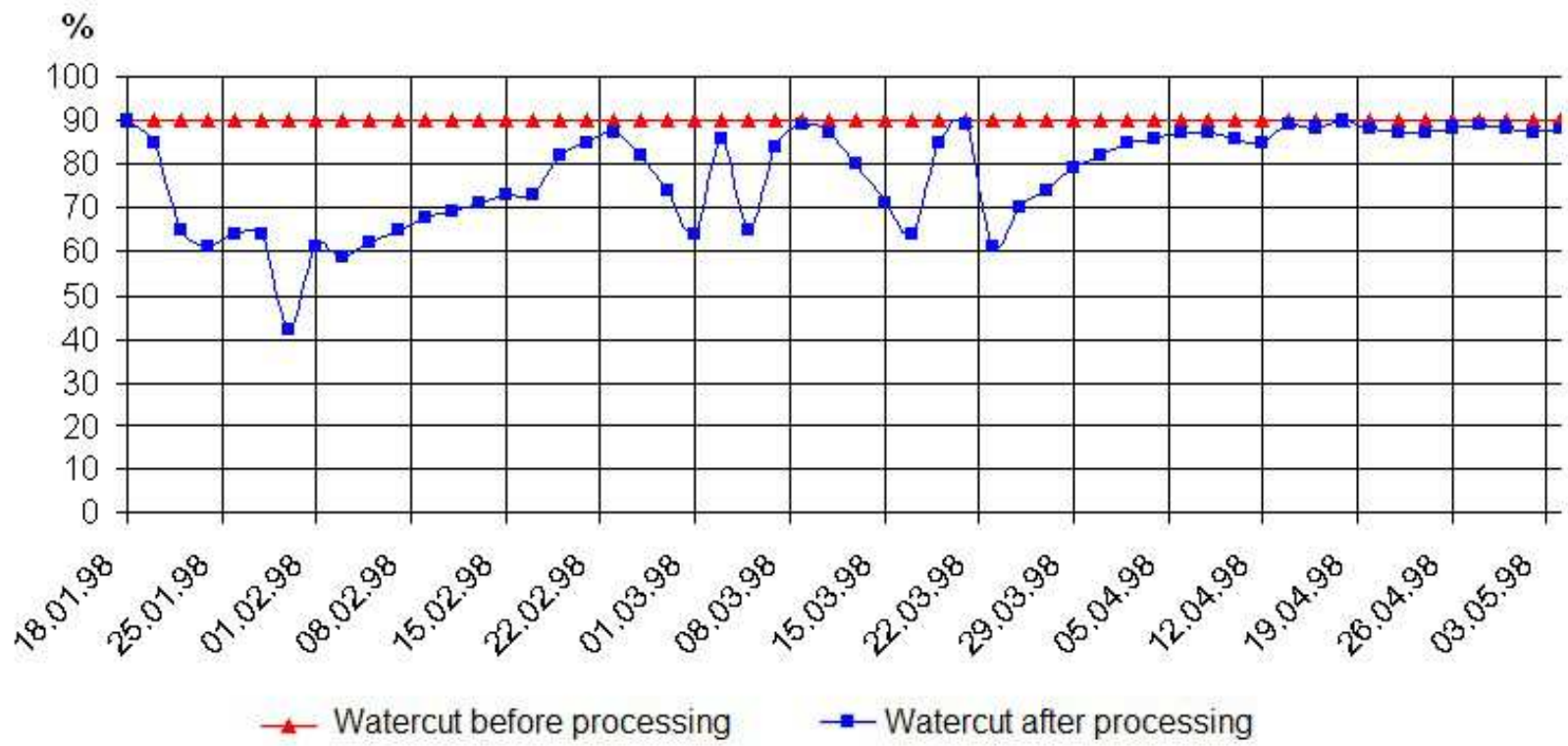

Figure 2 - Change in water cut after processing with hydrophobic material

The process of increasing the flow rate of watered wells is significantly influenced not only by the properties (physical and chemical) of the hydrophobic material "Ramsinks-2", but also by the permeability of the reservoir rock. Thus, the highest effect after treatment with hydrophobic material "Ramsinks-2" was obtained from well No 193 of the Zhyrnovsk field, where the permeability was $80 \mathrm{mDa}$ (Fig. 1).

In only four months, the additional flow rate at the well No 193 was 1 (one) thousand 19 tons (Fig. 2).

Mathematical modeling of oil change due to the action of the hydrophobic reagent "Ramsinks-2" in this article we carry out on two low-rate wells No 13-Stara Sil and No 862-Fosh of OGPD "Boryslavnaftogaz".

The obtained output data for the oil well No 13Stara Sil, which are given in the table number 2, we used to construct a mathematical model of the graph for increasing oil rate during the action time of the "Ramsinks-2" hydrophobic reagent.
After analyzing the data of well No 13-Stara Sil, we came to the conclusion that the obtained schedule most closely approaches the sinusoid (Fig. 3) of the form:

$$
y-y_{0}=A \sin \omega\left(x-x_{0}\right),
$$

where $\mathrm{A}=0.35, \omega=\pi / 3, \mathrm{x}_{0}=1.5, \mathrm{y}_{0}=1.42$.

As a result, an approximate equation is obtained.

$$
y=0.35 \sin \frac{\pi}{3}(x-1.5)+1.42, \quad x \in[0,10] .
$$

The equation is confirmed by the data of industrial works of well No 13 - Stara Sil in a sand reservoir with a permeability of up to $10 \mathrm{mDa}$.

The obtained otput data from the oil well No 862Fosh, given in Table 2. To construct a mathematical model of the graph we used increasing of oil flow rate during the action of the "Ramsinks-2" hydrophobic reagent. 
Table 1 - Depth of penetration of the suspension "Ramsinks-2"

\begin{tabular}{|c|c|c|c|c|c|c|}
\hline $\begin{array}{l}\text { Study } \\
\text { number }\end{array}$ & $\begin{array}{c}\text { Porosity } \\
\%\end{array}$ & $\begin{array}{l}\text { Saturation } \\
\text { fluid }\end{array}$ & $\begin{array}{c}\text { Initial } \\
\text { permeability, } \\
\text { mDa }\end{array}$ & $\begin{array}{l}\text { Length of cut } \\
\text { plates, mm }\end{array}$ & $\begin{array}{l}\text { Core permeability } \\
\text { after pumping of the } \\
\text { suspension, mDa }\end{array}$ & $\begin{array}{l}\text { Percent } \\
\text { from the } \\
\text { initial }\end{array}$ \\
\hline \multirow{5}{*}{1} & \multirow{5}{*}{15.8} & \multirow{5}{*}{ kerosene } & \multirow{5}{*}{29.1} & $0(\mathrm{~L}=48.5)$ & 15.3 & 52.5 \\
\hline & & & & $0.7(\mathrm{~L}=47.5)$ & 17.8 & 61.2 \\
\hline & & & & $6.9(\mathrm{~L}=41.6)$ & 18.9 & 64.9 \\
\hline & & & & $14.9(\mathrm{~L}=33.6)$ & 20.4 & 70.1 \\
\hline & & & & $23.0(\mathrm{~L}=48.5)$ & 23.1 & 79.4 \\
\hline \multirow{4}{*}{2} & \multirow{4}{*}{13.0} & \multirow{4}{*}{ kerosene } & \multirow{4}{*}{67.8} & $0(\mathrm{~L}=53.5)$ & 13.7 & 20.3 \\
\hline & & & & $0.7(\mathrm{~L}=52.1)$ & 20.4 & 30.2 \\
\hline & & & & $6.9(\mathrm{~L}=40.1)$ & 24.1 & 35.6 \\
\hline & & & & $23.0(\mathrm{~L}=36.5)$ & 27.8 & 41.1 \\
\hline \multirow{3}{*}{3} & \multirow{3}{*}{23.6} & \multirow{3}{*}{ kerosene } & \multirow{3}{*}{ - } & $0(\mathrm{~L}=49.7)$ & 3.2 & 21.3 \\
\hline & & & & $0.7(\mathrm{~L}=48.7)$ & 14.6 & 97.3 \\
\hline & & & & $6.9(\mathrm{~L}=36.7)$ & 14.7 & 98.0 \\
\hline
\end{tabular}

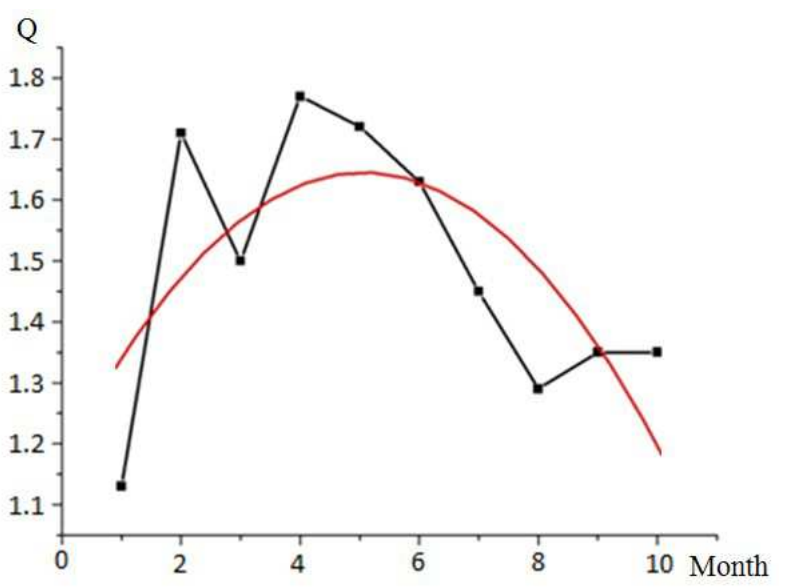

Figure 3 - Received sinusoidal graph

Table 2 - Output data for constructing a mathematical model

\begin{tabular}{|c|c|}
\hline Month & Q, t/day \\
\hline 1 & 1.13 \\
\hline 2 & 1.70 \\
\hline 3 & 1.50 \\
\hline 4 & 1.75 \\
\hline 5 & 1.73 \\
\hline 6 & 1.60 \\
\hline 7 & 1.45 \\
\hline 8 & 1.30 \\
\hline 9 & 1.35 \\
\hline 10 & 1.35 \\
\hline
\end{tabular}

Analyzed the data of changes in oil flow through well No 862-Fosh we came to the conclusion that the obtained schedule most closely approaches the catenoid (Fig. 3) of the form:

$$
y-y_{0}=A \cos h \omega\left(x-x_{0}\right),
$$

where $\mathrm{y}_{0}=1, \mathrm{~A}=-0.5, \mathrm{x}_{0}=6, \omega=1 / 6 \operatorname{arccosh} 1.76$.

As a result, an approximate equation is obtained

$$
y=-0.5 \sin \frac{\pi}{16}(x-6)+1, x \in[0,12] .
$$

As confirmed by the data of industrial works of well No 862-Fosh in a sand reservoir with a permeability of up to $16 \mathrm{mDa}$.

Catenoid is obtained in the case of teregenic (sand) with reservoir permeability of $15-20 \mathrm{mDa}$. The reservoir permeability of $20-200 \mathrm{mDa}$ and $200-2000 \mathrm{mDa}$ are in the study stage.

\section{As a conclusion}

1. The best conditions for using the "Ramsinks-2" reagent are the reservoir with an initial permeability of mineral water more than $15 \cdot 10^{-3} \mu \mathrm{m}^{2}$. At the same time, possible is the flow of water and oil, as well as the separate flow of oil and water on various sublayers (the latter conditions are the best application area, since the maximum effect of the use of the "Ramsinks-2" reagent of hydrocarbon suspension will be achieved).

2. Wetting agent "Ramsinks-2" was tested in two oil wells No 13-Stara Sil and No 862-Fosh. Extra production is 470.38 tons of oil. At the same time there is also an increase of the liquid flow rate of the well with a decrease of water cut by $9-12 \%$.

It is important to consider the possibility of increasing the oil recovery of productive formation under conditions of their water cut.

During operation, the share of water in the production of the well is constantly increasing. The reason for this can be blowouts of pumped water and various violations. In the first case, water flows from the productive formation to the most permeable zones. In the second case, water can flow through a shoe track of the wellbore, due to defects in the production column (cracks, shells in the metal, not tight threaded joints), due to the flow of water from one formation to another, resulting from the absence of isolation between them as a result of poor cementation quality. To reduce the proportion of water in the extracted product, it is proposed to use a composition of polyfunctional reagents, including hydrophobic substances based on silicone reagents (e.g., hydrophobic material "Ramsinks-2"), cationic surfactants, colmatering agents. The use of these compositions allows to change the phase permeability of the bottom-hole area of the 


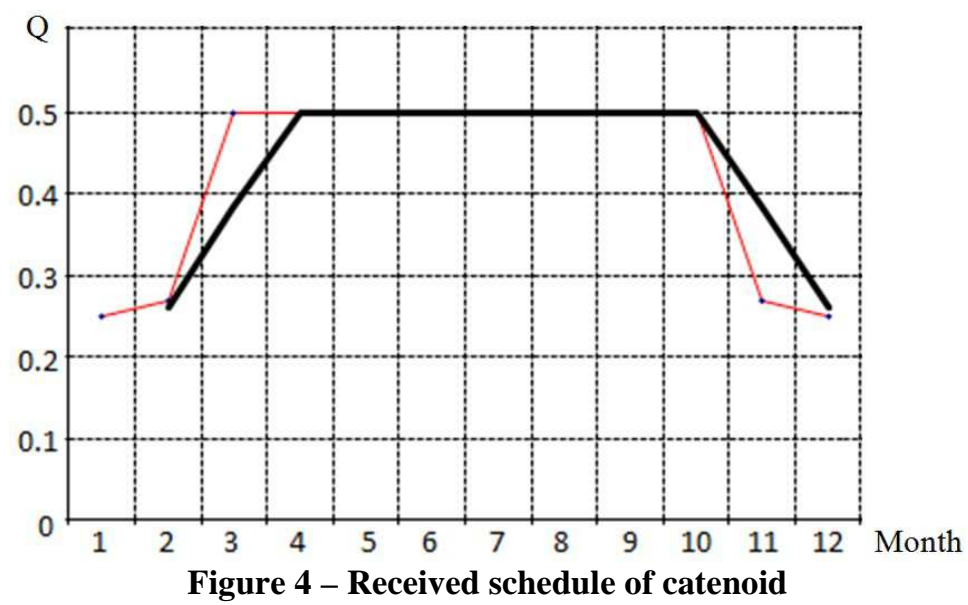

production wells in such a way that the water flow is limited and the inflow of oil increases.

To some extent, the issues of changes in the share of watercut production of oil wells today have been solved by applying the "Extract-700" reagent from the German company "Wacker-chemie GmbH" and developed by the Russian scientist - "Sidoks" Patent of England from 01.11.2000 WO 01/33039 A1 "Composition and process for oil extraction", the reagent "Polisil" (its modification "Retin") Ritek firm [2, 7].

Removing the formed layer and $1 \mathrm{~mm}$ plate leads to a practical restoration of permeability $-98 \%$ of the initial (Table 3). Increasing permeability increases the penetration of the suspension into the pore space. Thus, for a sample with a permeability of $29 \mathrm{~nm}^{2}$, the removal of a plate of a total length of $23 \mathrm{~mm}$ only allows to increase the permeability coefficient up to $80 \%$. For a sample with a permeability of $67 \mathrm{~nm}$, removal of approximately the same plate allows to increase the return permeability only to $43 \%$. It should also be noted that the substances in the composition do not harden in the rock, they are pumped using standard techniques in small quantities, which prevents the occurrence of problems in the development of the well. At the same time, in 2006-2008 we conducted laboratory researches of the advanced hydrophobic reagent "Silpan-SV" on core materials for the conditions of the Okhtyrka oil industrial district of PJSC "Ukrnafta" [5].

Hydrophobic dispersion material "Silpan-SV" is based on silicon dioxide, including a chemical modification of the surface of the starting material with an organometallic compound of the general formula $\mathrm{Cl}_{4}{ }_{\mathrm{n}} \mathrm{SiR}_{\mathrm{n}}$, where $\mathrm{n}=1-3, \mathrm{R}=$ methyl, ethyl, chloromethyl, phenyl, and basically it consists of silica in noncrystalline form.

The particles of the hydrophobic material "Silpan$\mathrm{SV}^{\prime}$ are a fine powder of white color, insoluble in water and, most of all, folded by spherical particles in the diameter of $0.07-0.09 \mu \mathrm{m}$. They have an extremely high surface area of $30-40 \mathrm{~m}^{2} / \mathrm{g}$. Their bulk density is $0.10-0.25 \mathrm{~g} / \mathrm{cm}^{3}$, humidity when stored in an open container no more than $0.05 \%$, the balance on a sieve with a grid No 0315 not more than $0.15 \%$. Material is relatively stable, inert, not sensitive to temperature changes.
Table 3 - Output data for constructing a mathematical model

\begin{tabular}{|c|c|}
\hline Month & Q, t/day \\
\hline 1 & 0.25 \\
\hline 2 & 0.28 \\
\hline 3 & 0.50 \\
\hline 4 & 0.50 \\
\hline 5 & 0.50 \\
\hline 6 & 0.50 \\
\hline 7 & 0.50 \\
\hline 8 & 0.50 \\
\hline 9 & 0.50 \\
\hline 10 & 0.50 \\
\hline 11 & 0.28 \\
\hline 12 & 0.25 \\
\hline
\end{tabular}

Laboratory studies were carried out under normal conditions on core material from well No 174Bugruvativska, selected in the interval 3876-3887 m, which is lithologically represented by quartz highly permeable sandstone (absolute permeability greater than $200 \mathrm{mDa}$ ). For research, part of the core was impregnated with water with mineralization of $\mathrm{NaCl}$ $40 \mathrm{~g} / \mathrm{l}$, and the second part was degassed with oil from the well No 202-Kachanivska with the creation of residual water saturation in the ratio of 70:30.

During the pilot studies to determine the influence zone of hydrophobization, the material "Silpan-SV" was used, which is an improved development of the "Ramsinks-2" material. First, the permeability of the cores with the saturation liquid was determined, after which a kerosene solution of the "Silpan-SV" reagent was pumped through the samples in an amount of 10 pore volumes, followed by holding it in the rock for 24 hours. After that, the permeability of the samples to the liquid saturation and the return permeability were determined.

Permeability and restoring coefficient was also determined after removing from the core edge a plate of 1 and $10 \mathrm{~mm}$ thick. The results of the studies are given in Table 4.

The results of the studies allow us to make the following conclusion: the "Silpan-SV" reagent, penetrating the pore space of the sample, leads to a partial decrease in the phase permeability of the oil-bearing 
Table 4 - Results of studies of the reagent "Silpan-SV"

\begin{tabular}{|c|c|c|c|c|c|c|}
\hline $\begin{array}{l}\text { Core } \\
\text { No }\end{array}$ & $\begin{array}{l}\text { Porosity, } \\
\quad \%\end{array}$ & $\begin{array}{l}\text { Saturation } \\
\text { liquid }\end{array}$ & $\begin{array}{c}\text { Initial } \\
\text { permability, } \\
\mathrm{mDa}\end{array}$ & $\begin{array}{l}\text { Length of the plate } \\
\text { that is cut, mm }\end{array}$ & $\begin{array}{c}\text { Core permeability after } \\
\text { suspension pumping, } \\
\mathrm{mDa}\end{array}$ & $\begin{array}{l}\% \text { from } \\
\text { the initial }\end{array}$ \\
\hline \multirow{3}{*}{11629} & \multirow{3}{*}{15.0} & \multirow{3}{*}{ oil } & \multirow{3}{*}{46.2} & $0(\mathrm{~L}=51.5)$ & 27.0 & 58 \\
\hline & & & & $1(\mathrm{~L}=50.5)$ & 27.7 & 61 \\
\hline & & & & $10(\mathrm{~L}=41.5)$ & 36.4 & 80 \\
\hline \multirow{3}{*}{11631} & \multirow{3}{*}{16.2} & \multirow{3}{*}{ oil } & \multirow{3}{*}{63.5} & $0(\mathrm{~L}=58.1)$ & 32.9 & 52 \\
\hline & & & & $3(\mathrm{~L}=55.1)$ & 41.3 & 65 \\
\hline & & & & $9(\mathrm{~L}=49.1)$ & 49.7 & 78 \\
\hline \multirow{3}{*}{11639} & \multirow{3}{*}{17.0} & \multirow{3}{*}{ water } & \multirow{3}{*}{118.7} & $0(\mathrm{~L}=49.3)$ & 17.9 & 15 \\
\hline & & & & $1(\mathrm{~L}=48.3)$ & 18.6 & 16 \\
\hline & & & & $10(\mathrm{~L}=39.3)$ & 15.5 & 13 \\
\hline \multirow{3}{*}{11632} & \multirow{3}{*}{15.8} & \multirow{3}{*}{ water } & \multirow{3}{*}{86.4} & $0(\mathrm{~L}=47.5)$ & 7.8 & 9 \\
\hline & & & & $1(\mathrm{~L}=46.5)$ & 8.6 & 10 \\
\hline & & & & $8(\mathrm{~L}=39.5)$ & 9.8 & 11 \\
\hline
\end{tabular}

Table 5 - Water permeability reduction of oil reservoir

\begin{tabular}{|c|c|c|c|c|}
\hline $\begin{array}{c}\text { Experiment } \\
\text { number }\end{array}$ & $\begin{array}{c}\text { Concentration of } \\
\text { hydrophobic } \\
\text { substance in } \\
\text { condensate, mass. \% }\end{array}$ & $\begin{array}{c}\text { Initial water } \\
\text { permeability of the } \\
\text { reservoir model, } \\
\mathrm{V}_{\mathrm{v}}, \mu \mathrm{m}^{2}\end{array}$ & $\begin{array}{c}\text { Water permeability of the } \\
\text { reservoir model after } \\
\text { hydrophobic treatment } \\
\text { substance, } \mathrm{V}_{\mathrm{wp}}, \mu \mathrm{m}^{2}\end{array}$ & $\begin{array}{c}\text { Permeability } \\
\text { decrease, } \\
\mathrm{n}=\mathrm{V}_{\mathrm{w}} / \mathrm{V}_{\mathrm{wp}}\end{array}$ \\
\hline 1 & 0.5 & 0.0715 & 0.0099 & 7.2 \\
\hline 2 & 1.5 & 0.0623 & 0.0067 & 9.3 \\
\hline 3 & 2.5 & 0.4127 & 0.0381 & 10.9 \\
\hline 4 & 3.0 & 0.0823 & 0.0076 & 10.8 \\
\hline
\end{tabular}

sample in oil (coefficient of renewal is $52-58 \%$ ) and a significant decrease in the phase permeability of the saturated sample with water (restoring coefficient 9-15\%). For the conditions of the Bugruvate oilfield, the penetration of "Silpan-SV" into the pore space is observed for a considerable distance. In the case of oilbearing samples, a partial increase in permeability (by $22-26 \%$ ) is observed with a decrease in core length. In the case of water-saturated samples, no significant changes in permeability are observed [6].

Compared to the results obtained in the study of the "Silpan-SV" reagent for the conditions of the Boryslav oilfield, an increase in the initial permeability of rock samples leads to an increase in the restoring coefficient for oil-bearing samples and permeability decrease for water-saturated samples. Thus, the renewal coefficient of oil bearing cores for the conditions of the Bugruvate deposit is $52-58 \%$, in contrast to the conditions of $20-52 \%$ for the Boryslav field. The renewal coefficient of water-saturated cores for the conditions of the Bugruvate oilfield is 9-15\% compared to $9-32 \%$ for the conditions of Boryslav oilfield. The obtained results indicate that the conditions of the Okhtyrka oil industrial region are more optimal for the selective action of the "Silpan-SV" reagent $[4,5]$.

Investigation of the joint filtration of oil and water through cores treated with a hydrocarbon suspension of the reagent "Silpan-SV" showed that the hydrophobization of the bottomhole zone leads to an increase of hydrocarbons in well production by approximately $7-15 \%$. It should be considered that water and kerosene were fed into the core by two different power device at the same flow rate (modeling of the active water-pressure regime). When modeling the natural reservoir development regimes (using a single power device through two containers separately with water and kerosene), the increase of hydrocarbons during hydrophobization of the wellbore zone is even greater and is about $30 \%$. If before the treatment through the sample only water was filtered, then after processing, kerosene appeared in the product.

The conducted experimental researches are as follows. Firstly, the conditions of the Bugruvate and Kachaniv oilfields are more optimal for the use of the "Silpan-SV" reagent in order to hydrophobize the bottomhole zone than the conditions of the Boryslav oilfield area. Secondly, in order to achieve the maximum effect when selecting objects, it is necessary to pay attention to the porous space of the reservoir with heterogeneous permeability by sublayers, i.e. separate water and oil supply conditions. In addition, experimental studies are still ongoing to determine the effect of the rate of filtration of formation fluids on the blocking effect of the "Silpan-SV" reagent in pore core space $[7,8]$.

\section{Conclusions}

Experimental studies to determine the effect of the filtration rate of reservoir fluids have shown an influence on the blocking effect of the "Silpan-SV" reagent in the pore space of the core. When achieving the maximum effect when selecting objects it is necessary to pay attention to the reservoir with heterogeneous permeability layers or areas, i.e. on the conditions for the separate inflow of water and oil. 
The proposed technological solutions, such as deep perforation, cleaning of the bottomhole zone and application of magnetic antiparaffin device (MAD), treatment of the productive formation with wetting agent with various acidic or surface active systems, constitute a system of measures aimed at changing the composition of the water-oil emulsion.

The use of hydrophobic materials "Ramsinks-2" and "Silpan-SV" in the wells allows almost completely to restore the filtration characteristics of the reservoir, increasing the oil component in the water-oil mixture.

\section{References}

[1] Nalivayko, AI, Rudyy, MI \& Polevoy, YuA 2005, 'Methods of increasing oil recovery and productivity wells in the conditions of oil fields of Ukraine', Scientific Bulletin of the National Mining University, no 12, pp. 15-21. (in Ukrainian)

[2] Levorsen, A 1970, Geology of oil and gas, Svet, Moscow. (in Russian)

[3] Patent RF No 2188933, kl. E21B37/06, E21B43/22. The way to increase well productivity / Nalivayko A.I., Marin V.I., Akchurin V.A. and all; Saratov State University named after N.G. Chernyshevsky; stated 15.05.2001, published 10.09.2002, 14 p. (in Russian)
[4] Nalivayko, AI 2015, 'Composition and process to increase oil recovery of productive formations and productivity of wells in the conditions of their watering', Scientific Bulletin of the Kremenchuk Mykhailo Ostrohradskiy National University, iss. 1(90), part 2, pp. 98-103. (in Ukrainian)

[5] Masket, M 2005, 'The flow of homogeneous liquids in a porous medium', Institute of Computer Studies, Moscow, Izhevsk. (in Russian)

[6] Useful model patent of Ukraine No 32045, Solutions for the selective treatment of oil reservoirs (Silpan-SV) / Pan'ko DA, Nalivayko AI, Rudyy MI \& Lapko SV, 2008, 12 p. (in Ukrainian)

[7] Yurkov, NI 2004, Physicochemical principles of oil production, Volgograd. (in Russian)

[8] Nalivaiko, OI, Vynnykov, YuL, Nalivaiko, LG, Melnikov, OL \& Reznichenko, AO 2016, 'Improving the quality of cementing the production casing by oil well cement slurry "Silpan-P" of group "Ramsinks-2M"', Collection of scientific articles «Energy. Energy saving and rational nature use», Kazimierz Pulaski University of Technology and Humanities in Rodon, iss. 1(6), pp. 26-36.

УДК 622.276 .344

\title{
Метод гідрофобізації та матеріал «Ramsinks-2» для підвищення дебіту обводнених нафтових свердловин
}

\author{
В. Н. Бабаєв, I. І. Капцов, О. І. Наливайко
}

Харківський національний університет міського господарства імені О.М. Бекетова; вул. Маршала Бажанова, 17, м. Харків, 61002, Украӥна

Розглянуто традиційні методи збільшення нафтовіддачі, а також нові підходи до вирішення цієї проблеми, наприклад, гідрофобізацією привибійної зони пласта з використанням полімерів. Особлива увага приділяється обробці результатів досліджень кернів обводнених свердловин 3 метою визначення коефіцієнту відновлення проникності після нагнітання гідрофобної суспензії "Ramsinks-2". Матеріал "Ramsinks-2" суттєво збільшує приймальність свердловини, знижує тиск нагнітання в результаті покращення проникності пласта. Показано, що застосування гідрофобних матеріалів "Ramsinks-2" i "Silpan-SV" дозволяє практично повністю відновлювати фільтраційні характеристики продуктивного пласта, збільшуючи нафтову складову у воднонафтовій суміші.

Ключові слова: гідрофобізачія, нафтовіддача, пласт, родовище. 